\title{
PROMOTING CREATIVE IMAGINATION OF NON-EXPRESSED NEEDS: EXPLORING A COMBINED APPROACH TO ENHANCE DESIGN THINKING
}

\author{
Samira BOURGEOIS-BOUGRINE ${ }^{1 *}$, Souad LATORRE², Florence MOUREY ${ }^{3}$ \\ ${ }^{1}$ Paris Descartes University, Institute of Psychology, Laboratoire Adaptations Travail Individu, \\ 71, Avenue Edouard Vaillant, Paris 92100, France \\ ${ }^{2}$ ESIEE Paris, Paris-Est University - d.school Paris at Ecole des Ponts \\ 2 bd Blaise Pascal, 93162 Noisy-le-Grand \\ ${ }^{3}$ Independent human factors and ergonomics consultant, Paris, France
}

Received 29 November 2017; accepted 26 November 2018

\begin{abstract}
Creativity is vital to radical innovation for the generation of new and disruptive ideas. Managers, practitioners and teachers are increasingly integrating design thinking approach to stimulate creativity and innovation. Design thinking implies empathy as an innovation mind-set to understand the latent needs of users observed in real settings. However, it has been suggested that radical innovations do not come from a user-centred approach such as design thinking and that design thinking is often based on anecdotes than data and that its value is difficult to prove. The aims of this paper is to propose an approach to enhance design thinking in educational setting in order to promote radical innovation mindset. Drawing on the benefits of prospective ergonomics, digital mock-up and virtual environment to promote ideation and empathy, the proposed approach takes as a starting point the imagination of future needs using prospective scenarios approach, instead of users' latent and unmet needs, for the development of artefacts and services that would change social practices. The paper a) discusses why and how this combined approach would foster students' radical innovations skills by not just satisfying actual users' needs but by imagining and anticipating new needs and $b$ ) propose a method to evaluate the effectiveness and the efficacy of design thinking enhancement.
\end{abstract}

Keywords: creativity, design thinking, digital technology, education, ergonomics, innovation, need-seekers, prospective ergonomics.

\section{Introduction}

Many of the problems we face in real life are ill-structured, including important social, political, economic, and scientific problems in the world. Contrary to well-structured problems, ill-structured problems are characterised by a vague description: the information needed to solve the problems is not provided in the problem statement, they may possess multiple

${ }^{\star}$ Corresponding author. E-mail: samira.bourgeois-bougrine@parisdescartes.fr

This is an Open Access article distributed under the terms of the Creative Commons Attribution License (https://creativecommons. org/licenses/by/4.0/), which permits unrestricted use, distribution, and reproduction in any medium, provided the original author and source are credited. 
solutions and there is no universal agreement on the appropriate solution. Finding innovative and creative solutions to the challenges of the 21st century requires a shift in educational and learning practices for fostering the development of the innovation-related skills among students. Education systems are required to prepare students to demonstrate core subject mastery as well as innovation and interpersonal skills (Yang, 2018; Seelig, 2012; Baillie, 2002). Based on a consensus from various institutions and organizations across the world, ${ }^{1}$ a focus on the 4C's (creativity, critical thinking, communication, and collaboration) of 21 st century skills is essential for providing the next generation of innovators with the resources they need in order to face the challenges of today and tomorrow.

A growing number of managers, practitioners and teachers in engineering design are integrating design thinking (DT) to stimulate innovation and is part of the curricula in many renowned management and engineering schools such as Stanford University and Harvard Business School (Wrigley, Mosely, \& Tomitsch, 2018; Altman, Huang, \& Breland, 2018; Carlgren, Elmquist, \& Rauth, 2016; Brown \& Katz, 2011; Dym Agogino, Eris, Frey, \& Leifer, 2005; Norman \& Verganty, 2012; Patnaik \& Mortensen, 2009; Seidel \& Fixson, 2013). DT is defined as a human-centred approach to innovation that draws from the designer's toolkit to integrate the needs of people, the possibilities of technology, and the requirements for business success (Brown, 2009; Liedtka, 2015). However, it has been suggested, as we will see in the next section, that radical innovations do not come from a user-centred approach such as DT. Radical or disruptive innovation has a significant impact on the economy by creating new markets while incremental innovation leads to the improvement of existent products or services. The Global Innovation 1000 study (Jaruzelski, Staack, \& Goehle, 2014), which distinguishes three profiles of innovative companies, indicates need-seekers (NSs), with a culture oriented towards understanding end-user needs and behaviours, such as Apple Inc., often respond to non-expressed needs and are the first to market new products and services. They are therefore more efficient than "technology drivers" companies or "market readers" who take a more cautious approach with incremental innovations to their products. Clayton M. Christensen (interview in McGregor, 2007) considers that "big technological leapfrogs rarely create new growth. Almost all of them are defensive in character. The equation of disruptive, with new and radical, causes people to target markets that don't exist".

How can we improve education and training to promote the acquisition of radical innovation skills in higher education? To answer this question, this paper aims to propose the conceptual design of an education approach to enhance DT training in order to promote radical innovation by anticipating non-expressed needs. The approach combines DT and prospective ergonomics (PE), which invites to anticipate future needs, habits and behaviours, as well as the use of digital tools and virtual environment to support the innovation process. Thus, contrary to the approach of taking as a starting point users' known and unmet needs for the development of artefacts or services, we propose in this paper a new approach that combines the tools and principles of the DT, those of PE virtual and digital tools in order to think of future needs and develop scenarios of uses as well as prototypes of the selected strategic solutions. It is the result of the identification of a) the pitfalls of our experience of teaching and

\footnotetext{
1 Source: Framework for 21st Century Learning (P21: Partnership for 21st Century Learning, 2018).
} 
facilitating DT and creativity workshops in education setting (Bourgeois-Bougrine, Sandoz, Allena, \& Dallez, 2015; Bourgeois-Bougrine, Buisine, Vandendriessche, Glaveanu, \& Lubart, 2017), b) the benefits of PE in the creation of future services, products and systems (Brangier \& Robert, 2014) and c) the recent advances that suggest that digital mock-up (Latorre, Markowski, \& Pointet, 2016) and virtual environment promotes ideation and empathy (Guegan et al., 2016; Buisine, Guegan, Barré, Segonds, \& Aoussat, 2016; Bourgeois-Bougrine, Richard, Lubart, Burkhardt, \& Frantz, 2018).

The paper is structured in three sections. The first section addresses the benefits and limitations of DT in the field of the management of innovative projects in education setting. In the second section, we introduce the concept of ergonomics and prospective methods. A dual approach to anticipate needs, uses and future behaviours is proposed in the third section. This last section includes a) a presentation of the combination of the principles of DT and those of PE in particular prospective scenarios, b) a discussion of the potential benefits of digital mock-up and virtual environment in promoting ideation and empathy are discussed and c) a description of the evaluation method of the efficiency and efficacy of this combined approach.

\section{Introduction to design thinking}

Roberto Verganti (2010) indicated that "we are used to thinking about innovation in terms of technologies [...] but we always forget that people don't buy just utility. People buy meaning and emotion and symbols". The success of the introduction of a new product depends on the satisfaction of customers' needs, their willingness to adopt the product and even to change their behaviours (Leifer \& Steinert, 2011). Daniel H. Pink (2006, p. 2) considers that "the future belongs to a very different kind of person with a very different kind of mind - creators and empathizers, pattern recognizers, and meaning makers".

DT emphasizes empathy (Patnaik \& Mortensen, 2009) as a state of mind to innovate, which implies to start by understanding the latent needs of people through observation in real contexts. Those observations generate insights, which are translated into innovative products through iterations with quick-and-dirty prototypes in order to collect feedback from the field and users. "Design thinking is a discipline that uses the designer's sensibility and methods" (Brown, 2009). To benefit from DT, one needs to think and act like a designer to a certain extent. According to Don Norman (2013, p. 219),

\footnotetext{
"design thinking is not an exclusive property of designers - all great innovators have practiced this, even if unknowingly, regardless of whether they were artists or poets, writers or scientists, engineers or businesspeople. But because designers pride themselves on their ability to innovate in finding creative solutions to fundamental problems, design thinking has become the hallmark of the modern design firm".
}

The DT process consists of 5 iterative steps: empathize, define, ideate, prototype, test. The Paris-Est d.school bootcamp bootleg developed by Stanford University is a toolkit to support DT practice (Plattner, 2010). It outlines each mode of a human-centered design process, and then describes dozens of specific methods to do design work. It includes a set of tools to help designers move through the "three spaces of innovation" (Brown \& Katz, 2011, p. 383): 
inspiration (e.g. the problem or opportunity that motivates the search for solutions), ideation (e.g. the process of generating, developing, and testing ideas), and implementation (e.g. the path that leads from the project room to the market).

The inspiration-exploration phase is aimed at identifying problems and expectations. This is a phase where the team gathers information from different sources. The field favours the multiplication of ideas, the appropriation of the problem by the team and thus the development of the motivation and the empathy within the team. The mastery of ethnographic research is essential for understanding the context of use and users and therefore the generation of ideas and solutions. Ethnographic research is crucial in the overall approach of the DT both to the definition of needs and to the design of relevant and creative solutions. It relies on several tools (interviews, photos, videos, etc.) in order to enable students to immerse themselves in the user experience in context as well as to collect perceptions at different stages of the project.

During the "conceptualization" or implementation phase, teams are encouraged to quickly test the first solutions envisaged using rudimentary prototypes in order to demonstrate their relevance. Investing directly in sophisticated prototypes presents the risk of leading them quickly on the convergence process and therefore not exploring all options. This highly experimental approach, by which the project is refined, co-developed through successive confrontations with the field and the user's expectations, reduces the likelihood of disillusions that a team can experience at later stage of the project. Before the final prototype, the teams have the possibility to use different prototyping tools according to the stages of the project: drawing, cardboard, digital mock-up, 3D printing. The main objective of the various prototypes, whatever their nature, remains to be able to collect feedback from the users regarding the relevance of the imagined solution(s).

Teams improve by iterating their solutions or scenarios and consequently their prototypes during the different sessions and phases of the project, as well as by learning to master creative tools such as brainstorming or visual thinking (visual thinking is a way of thinking that relies heavily on the process of processing visual information by the brain). Working in project mode within multidisciplinary teams provides students with the opportunity to develop their competence to work with collaborators with multiple profiles, which is often the case in a professional context.

\subsection{Design thinking limits}

Despite the growing popularity of the DT, it should be mentioned that this is not a new process, "it is a new name for an old method" (Iskander, 2018) and there is a little evidence of successful impact (Carlgren et al., 2016). Natasha Iskander (2018) considers that DT is poorly defined, based on anecdotes than data and it is a little more than basic common sense. As shown in Table 1, DT is the subject of much criticism from researchers and designers themselves (Nussbaum, 2011; McCullagh, 2010). For some, it would be better to speak of "design-doing" instead of DT because of the strong orientation towards concrete action, fast or even temporary solutions. This bias towards action can lead to the implementation of a technical solution without really taking the time to engage in a genuine reflection about the root causes of the problem to be solved. According to Danny Buerkli (2013), it is not surpris- 
ing that this approach has flourished in the Silicon Valley where the dominant belief is that technology is able to solve all our problems ("there is an app for that"). No single method can be applied to all types of problems and technological solutions may be inappropriate when the problem is socio-economic.

Others argue that radical innovations do not come from a user-centred approach (Norman \& Verganti, 2012). Empathy towards users makes it possible to understand their needs and results in an incremental improvement of what already exists or in the development of a product or service to satisfy those needs. Christensen, considers that

"the problem is when you say 'listen to your customers', your customers are only going
to lead you in a direction that they want to go in. Generally, that will never lead you to
disruptive growth. You've got to find that new set of customers, and listen to them and
follow them. That's the trick. Once you have customers, they hold you captive to their
needs [...] You have to be careful which customers you listen to, and then you need to
watch what they do, not listen to what they say" (interview in McGregor, 2007).

Furthermore, in the past few years, users have been increasingly involved in the development of new products. This is mainly motivated by the idea that users have knowledge of their own needs and are able to develop solutions that fit those needs (Kujala, 2003; Kristensson \& Magnusson, 2010). Per Kristensson, Peter R. Magnusson and Jonas Matthing (2002, p. 12) indicated that professional developers and advanced users created significantly less original and valuable ideas than ordinary users when given the task of creating ideas for future mobile phone services. The authors suggested that divergent thinking may be inhibited by aspects of earlier knowledge and experience in terms of what was more or less technically producible. A recent analysis of the uses of DT in industry (Carlgren et al., 2016, p. 354) showed that "despite education and training in DT, interviewees described how many employees found it difficult to apply it in their own contexts after training". In addition, there were several challenges that are related to the main core themes of DT, e.g. user focus, problem framing and iteration. One of the most important challenges was related "to presenting or arguing for an idea based on subjective, human oriented values data". Engineers and managers perceived user insight as unspecific when is not directly translated into technical requirement. In addition, insight gained and the reformulation of the initial problem may result in ideas and concepts that are difficult to implement if they are outside the scope of the company's product planning. The iterative and explorative approach of DT is resource intense and clashes with "the linear, efficiency-oriented processes of incremental product development" (Carlgren et al., 2016, p. 347). In addition, other cultural elements of DT, such as having fun, testing quickly hypothesis, interacting with users, failing and learning from mistakes were perceived as challenging for companies with a strong risk-averse culture and is reinforced by national cultures.

Yet, radical innovation is only possible if the company overcomes the internal and external innovation barriers, break out form old mindset and unlearn existing routines and old logic (Assink, 2006). The hill-climbing paradigm ${ }^{2}$ applied to incremental and radical

\footnotetext{
2 Hill climbing is a mathematical optimization technique that attempts to find a better solution by incrementally changing a single element of the solution. If the change produces a better solution, an incremental change is made to the new solution, repeating until no further improvements can be found (Wikipedia: The Free Encyclopedia, 2018).
} 
innovation suggests that incremental innovation attempts to reach the highest point on the current hill, radical innovation seeks the highest hill (Norman \& Verganti, 2012). Radical innovation implies a break with the past, either through the introduction of a new technology, a paradigm shift or through a new vision that comes from a deep reinterpretation of the meaning of a product or service in line with socio-cultural changes. Users have difficulty anticipating their needs or considering this reinterpretation because of their total immersion in the current context and in the cultural paradigm. Iskander (2018) argues that DT is fundamentally conservative, unsuited to uncertainty, and preserves the political, economic, and physical status quo.

These challenges and limits at both individual and organisational levels in implementing DT entail a need for engineering students to develop the ability to discard outdated mental models, to adopt radical innovation mindset and "transfer" these skills to professional environment. The approach we will present in the next section aims at enhancing student DT training in order to imagine non-expressed needs, to explore radical new ideas and concepts that would have the potential to change social practices and create new products, process and services. It involves the use of structured and rigorous prospective methods anchored in the principals of DT and Ergonomics that share common aims: "ensuring that the resulting product is understandable and usable, that it accomplishes the desired tasks, and that the experience of use is positive and enjoyable" (Norman, 2013, p. 219). Indeed, prospective is not intended to predict the future or to reveal it as if it were something that already exists (Jouvenel, 2002), but rather invites it to be constructed. Prospective uses rigorous methods of quantitative, qualitative, normative or exploratory nature (Gordon \& Glenn, 2004): agent modelling, bibliometrics, causal layered analysis, decision modelling, Delphi techniques, scenarios, morphological analysis, road mapping, text mining, trend impact analysis, future wheel, etc.

Table 1. Summary of design thinking process and main challenges (source: created by authors)

\begin{tabular}{|c|c|c|}
\hline \multicolumn{2}{|c|}{ Design thinking process } & Main challenges/limits \\
\hline \multicolumn{2}{|c|}{ Inspiration-exploration } & \multirow{7}{*}{$\begin{array}{l}\text { - Users have difficulty anticipating their needs; } \\
\text { - Incremental improvement of what already ex- } \\
\text { ists; } \\
\text { - Preserves the political, economic, and physical } \\
\text { status quo; } \\
\text { - Iterative and explorative approach of design } \\
\text { thinking clashes with "the linear, efficiency-ori- } \\
\text { ented processes of incremental product devel- } \\
\text { opment; } \\
\text { - Failing and learning from mistakes were per- } \\
\text { ceived as challenging for companies with a } \\
\text { strong risk-averse culture; } \\
\text { - Cultural elements of design thinking, such as } \\
\text { having fun or interacting with users could be } \\
\text { challenging in organisations. }\end{array}$} \\
\hline & $\begin{array}{l}\text { - Empathy towards users to } \\
\text { gain insight on their needs }\end{array}$ & \\
\hline Define & $\begin{array}{l}\text { through ethnographic re- } \\
\text { search; } \\
\text { - Challenge the initial problem/ } \\
\text { expand problem formulation/ } \\
\text { avoid jumping to initial solu- } \\
\text { tions. }\end{array}$ & \\
\hline \multicolumn{2}{|l|}{ Ideation } & \\
\hline Ideate & $\begin{array}{l}\text { Process of generating and } \\
\text { developing ideas. }\end{array}$ & \\
\hline \multicolumn{2}{|c|}{ Implementation-conceptualization } & \\
\hline $\begin{array}{l}\text { Prototype/Test/ } \\
\text { Iterating }\end{array}$ & $\begin{array}{l}\text { Rudimentary prototypes } \\
\text { (drawing, cardboard, digital } \\
\text { mock-up, 3D printing). }\end{array}$ & \\
\hline
\end{tabular}




\title{
2. Ergonomics and prospective
}

Ergonomics is a scientific discipline concerned with the understanding of interactions among human and other elements of a system, as well as the profession that applies theory, principles, data and methods to design in order to optimize human well-being and overall system performance (see iea.cc, 2018). It explores human physical and mental capabilities and limitations and uses this knowledge to improve the design of things that people use such as office equipment and systems, technology for assisting disabled individuals, power plant control rooms, spacecraft, educational and training materials, medical devices, and consumer products (American Psychological Association, 2018). Ergonomics, also known as human factors engineering in the United States, emerged during World War II for improving the performance and safety of military systems, as well as human productivity and quality of life. Although job and task analysis remain the most popular methods used by ergonomists, Neville A. Stanton, Alan Hedge, Karel Brookhuis, Eduardo Salas and Hal W. Hendrick (2005) reported almost 90 methods framed by the classic onion-layer analysis model, working from the individual, to the team, to the environment, to the work system. Three of the methods categories are concerned with the individual person and his or her interaction with the world (i.e., physical methods, psychophysiological methods, and behavioural-cognitive methods); one addresses the social groupings and their interaction with the world (i.e., team methods); another of category encompasses the effect that the environment has on people (i.e., environmental methods) and the last of the methods categories concerns the overview of work systems (i.e., macro-ergonomics methods).

Ergonomists are often required to correct artefacts in order to limit their negative impact on health and safety as well as increase job satisfaction and human performance. However, their sphere of influence is limited compared to engineers and designers who have a greater opportunity to eliminate hazards and risks at the source. The ability to influence safety is linked to the "ability to utilize higher order controls", e.g. elimination, substitution, engineering (Behm, Culvenor, \& Dixon, 2014). By eliminating hazards at source early in the design stage, the cost impact to the project will be minimised. Therefore, ergonomists are increasingly involved in early stages of the design including innovation projects.

The work of Éric Brangier and Jean-Marc Robert contributed to linking ergonomics to the discipline of prospective (2014). PE consists of

\begin{abstract}
"anticipating future needs, uses and behaviours or building future needs in order to create processes, products or services adapted to them. By integrating prospective methods, the discipline of ergonomics has broadened its scope to encompass the study of the future and the creation of future services, products, systems. This means that ergonomists missions are no longer confined to correcting and helping to design artefacts to eliminate or reduce health and safety hazards but they are also involved in activities of creation and innovation" (Brangier, Barcenilla, \& Robert, 2017, p. 48).
\end{abstract}

Based on the taxonomy of Theodore J. Gordon and Jerome C. Glenn (2004), prospective methods (PMs) have been grouped into 5 categories by Brangier and Robert (2014):

- methods based on the collection of expert judgments,

- methods based on quantitative measurements,

- methods of analysis and understanding of the links between events, trends and actions, 
- figurative methods to help actors think about the future,

- projective methods.

According to Robert and Brangier (2009, p. 166), "prospective ergonomics seems ready to be adopted judging from young ergonomists' reactions. In our teaching, we encounter numerous graduate students coming to human factors from different design-oriented disciplines (e.g., industrial design, graphic design, engineering, computer science, architecture, information systems). They end up with multiple competencies in human factors and in design, engineering, computer science, management, and sociology. Some of them, who are both innovative and endowed with an entrepreneurial mindset, want to pursue their design activity in human factors projects. Prospective ergonomics seems natural to them because it offers an opportunity both to innovate and have an impact on others' lives".

\section{Combined approach to managing innovative projects}

This section will present combined approach of DT and scenario, one of the most popular $\mathrm{PE}$, and explore research in PE and virtual reality (VR) to address two specific topics: the potential use of VR for promoting the production and the exchange of ideas without production blocking and VR for learning empathy-related abilities.

By combining the methods of PE and DT, our approach would start with anticipating and building non-expressed needs and would result in scenarios of uses and prototypes of the strategic solutions chosen. This combined approach involves both analytical and intuitive thinking, imagination and creativity as well as collaboration and communication within multidisciplinary teams of mentors and students. A typical pedagogical design should last between 3 to 6 months depending on the scale of the local initiatives.

In a previous study (Bourgeois-Bougrine et al., 2017), we found that the passive delivery method (e.g., lecture-based instruction) of creativity tools and the use of only one "treatment" or exposure was not effective in promoting student's proficiency to effectively use these tools. Therefore, students should be introduced to prospective methods while addressing real challenges or projects. The learning-based project is considered as one of the more effective ways for students to learn by active experiencing (Dym et al., 2005; Scott, Leritz, \& Mumford, 2004). Prospective projects (PPs), considered in agreement with industrial partners, should be concerned with future human activities related to the industry 4.0 or smart factory as well as the transport of tomorrow, sustainable city, smart food, future medicine, ecology, etc. (economie.gouv.fr, 2015). Concepts, methods and tools of PE should be introduced in this phase of the project.

\subsection{Prospective scenarios and design thinking}

Scenario has formed a core component of a strategic development course taught at different universities (O’Brien, 2004; Wright, Cairns, \& Goodwin, 2009). The main focus of scenarios is to address the uncertain aspects of the future to help people imagine, organize and anticipate the future in multiple plausible images. It is a story about how the future might unfold for the purpose of technology and business strategy development. Scenario approach is often used in combination with other techniques such as Delphi (Cairns, Wright, Fairbrother, Phil- 
lips, 2017), resource mapping (Kunc \& O’Brien, 2017) or technology road map (Hussain, Tapinos, \& Knight, 2017).

Scenario approach is based on the intuitive-logics school (Bradfield, Wright, Burt, Cairns, \& Heijden, 2005) and typically covers three phases (Kunc \& O’Brien, 2017; McKiernan, 2017): preparation, development and use. These phases are linked through feedback loops and include various iterative stages such data collection, analysis, synthesis, exploration of key issues, scenario building, scenario writing, scenario testing, and redefining.

The preparatory phase precedes the scenario workshops and involves a set of interviews with the key actors of the organization who have agreed to participate, extensive research (organisation's data, technology foresight websites, on-line communities, research papers, global events, etc.) as well as ergonomic analysis of contexts, users' tasks and activities, cognitive models, norms, etc. The large and unstructured amount of data collected from multiple sources is analysed, synthesized into themes and explored for drivers of future change. This phase mirrors the first stage of DT (e.g., inspiration-exploration phase) but goes beyond ethnographic analysis of users' needs. It involves a structured approach of collecting and analysing the data, identifying and extracting the key drivers, patterns, models or trends. Different qualitative and quantitative techniques are usually used such as the methods of text mining, latent semantic analysis, SWOT (strengths, weaknesses, opportunities, and threats) analysis, PEST analysis or STEEPLE (political, economic, social, technological, environmental, legal and ethical factors) analysis, etc.

Once the focus of the exercise, the future horizon and driving forces are agreed upon, with the help of the key organisation's actors, the development phase starts. The scenario workshops should lead to the development of 3 to 4 scenarios building on the drivers identified in the data set using a structured or semi-structured method (McKiernan, 2017). Next step to writing the first draft of the scenarios is testing them with the key organisation's actors for plausibility. The students should be encouraged to be creative regarding the content and the way of presenting a scenario narrative. It is not only about generating ideas such as in the ideation phase of DT, but the scenario development involves writing tomorrow's fictions in a mix of art and science. David Pescovitz (2013, p. 11) reminds us that "science fiction has always been a place of technological innovation, even inspiring real-world inventions like the submarine and cell phone". He even asked writers of speculative fictions to write short stories tied to the theme of his research to forecast From Beyond the Coming Age of Networked Matter:

\footnotetext{
"We scanned science and technology journals to understand the technical underpinnings that would enable matter to network in new ways. And we also opened our eyes and minds to what artists had to tell us [...] We asked these writers to envision a world where humans have unprecedented control of matter at all scales, and to share with us a glimpse of daily life in that world. It was a process meant to make the future tangible" (Pescovitz et al., 2013, p. 11).
}

The final draft of the developed scenarios is used to inform strategic conversation with the organisation and strategy recommendations to product development. Once an innovative and futuristic challenge is chosen, student enter a new cycle of the DT process according to the above-mentioned five-step model: empathize, define, ideate, prototype, test. These steps 
involve the art of thinking through drawing (visual thinking), ethnographic research and other sources of inspiration (science fiction, biomimicry, cultural and historical benchmarks, etc.), the art of telling a story (storytelling).

In previous study (Bourgeois-Bougrine et al., 2017), we found that most engineering students were not confident in their ability to find innovative solutions, some were not aware of their creativity potential suggesting low creative self-efficacy. In addition, the analysis of students' workbooks showed that some of the creativity and development techniques were not very well mastered leading to a poor execution and weak benefits. The pedagogical design should therefore involve a mentoring committee composed of innovators and experts to assist the student teams throughout the whole process. The committee should help them learn how to be innovative, gather insights, conduct user tests, build a business plan, conduct technology and patent watch, present and defend a case, etc. As Erica McWilliam (2009, p. 8 ) suggested that creativity teachers should extend

\footnotetext{
"their pedagogical repertoire, beyond 'Sage-on-the-Stage' or 'Guide-on-the-Side', to include a third role for the 21st century teacher as a builder of creative capacity that of 'Meddler-in-the-Middle' [...]. [This last pedagogical category] is descriptive of active interventionist pedagogy in which teachers are mutually involved with students in assembling and/or dis-assembling knowledge and cultural products [...]. Meddling is a re-positioning of teacher and student as co-directors and co-editors of their social world".
}

This would potentially improve the effectiveness of creativity trainings as well as the students' creative self-efficacy, which consequently will affect positively their creative performance (Mathisen \& Bronnick, 2009).

\subsection{Exploring digital technology to support empathy and ideation stages}

While drawing is used as a graphic facilitator to develop creativity and support interactivity in the "ideation" phase of DT, a digital tool can also be an effective means for shaping "the imaginary". Creating forms becomes a matter of a couple of moves. The drafts, in turn, allow clearer communication within the creative team, and projected goals and ideas can be refined in real time. This visual interaction can be considered a genuine cognitive tool to stimulate areas of the memory that are not taken into account in the analytical description of a mental image (Ware, 2008). Furthermore, when these tools are then combined with virtual reality, they enable the user to illustrate not only the static forms of imagined solutions, but their staging, as well.

This approach, through dialogue and integration, puts the user in control of the whole design (Shin, 2018). Thus, these 3D models allow validation tests, in the form of virtual prototypes and/or physical prototypes made with $3 \mathrm{D}$ printing methods.

In addition, digital tools facilitate the traceability of ideas during the "diverging" phase as well as storing, backtracking, duplicating or reusing different drafts. They also allow for better continuity in content, sharing outside scheduled sessions, all the more when the teams come from mixed backgrounds and work for partner institutions as in projects carried out within the framework of the Paris-Est d.school (dschool.fr, 2018). 
PPs, as we have seen, involves multidisciplinary teams. Studies in ergonomics and management sciences have suggested difficulties related to the collaboration between users and experts such as divergences in perceived roles and interests (Cahour, 2002), difficulties for users to consider things in a long-term perspective and tendency of experts to reject systematically users' propositions due to their supposed lack of capacity (Buur \& Matthews, 2008). Furthermore, "productivity loss" has been reported in brainstorming groups. This has been linked to social inhibition due to evaluation apprehension, the impossibility to say two ideas aloud at the same time (production blocking), the tendency to suggest ideas too similar to others (fixation) and the tendency to rely on the group to suggest ideas (social loafing) (for a review see Diehl \& Stroebe, 1987).

One of the solutions that allows for an exchange of ideas without production blocking is to hold ideation tasks in virtual environments. Recent researches have shown that multiuser virtual environments hold the potential for greater creativity support due to behavioural modulation in situations of physical isolation, the anonymity of the users and the avatar appearance (Guegan et al., 2016; Buisine et al., 2016; Thornhill-Miller \& Dupont, 2016; Bourgeois-Bougrine et al., 2018).

It has been suggested that conducive, safe, and comfortable environments elicit global processing and exploration, because, in this kind of atmosphere, individuals are more eager to take risks (Friedman \& Förster, 2010) and that the perceived freedom from constraints triggers a risky, explorative processing style that promoted creativity (Steidle \& Werth, 2013). In our study, we observed that virtual environment, by offering a "freeing" atmosphere, cognitively disinhibited users with high risk-taking propensity, divergent thinking and mental flexibility abilities all leading to the emergence of creative ideas (Bourgeois-Bougrine et al., 2018).

Furthermore, Jérôme Guegan et al. (2016) found significantly higher fluency and idea uniqueness when engineering students embodied an "inventor" avatar as compared to the same situation using an uncreative-stereotypical avatar. This effect, known as the "Proteus effect" (Yee, Bailenson, \& Ducheneaut, 2009), could be explained by (i) self-perception: according to this theory, participants would be particularly sensitive to social cues associated with the new identity that they infer from their avatar; and (ii) priming: the avatar is able to activate in the memory concepts that are associated with its appearance.

In a recent review, Philippe Bertrand, Jérôme Guegan, Léonore Robieux, Cade Andrew McCall and Franck Zenasni (2018) indicated that virtual reality trainings promote different empathy related-phenomena such as perspective taking which is the cognitive ability of imagining the perspective of others, to understand the experiences, the feelings and emotions of others and show compassion and altruism. Virtual reality allows individuals to step into someone else's shoes, through a perceptual illusion called embodiment or the body ownership and to move their perspectives to different scenarios and universes.

Therefore, virtual environments should be more explored in terms of the embodiment of various personas to foster empathy and co-creativity when involving users (Brangier \& Robert, 2014). 


\subsection{Training evaluation}

One of the frequent critics of DT is that it is difficult to prove the value of DT as it is mainly based on anecdotes. Therefore, it is vital to evaluate the effectiveness and efficiency of the training combining creativity techniques, DT and PE for short- and medium-terms. The assessment method is based on the combined use of Donald Kirkpatrick's training evaluation model (Kirkpatrick Partners 2009-2018), the multivariate approach of creativity developed by Todd Lubart $(1999,2003)$ and the reflective practice according to the model of David A. Kolb (1984) and Graham Gibbs (1988).

The evaluation of the short-term impact of the training should consist of observing the students in situation and conducting structured interviews in order to identify the progress and to identify the new behaviours implemented (actions and observable reactions). These observations and interviews should take place throughout the implementation of the group projects. Interviews should focus on their goals and actions during the session (e.g. what were your goals and plans for this session? What have you done exactly during this session? How do you feel about the advance of your project?). In addition, to assess the dynamics of the creative process, students should be asked to complete a workbook with a) an open part (blank pages) in which participants are invited to record their progress, reflect and describe their approach, its development and creativity techniques used, make free comments and produce drawings and sketches for different stages of the project and b) a checkbox question to allowed the participants to select (tick a box) the stages that correspond to their creative approach and problem solving among various stages (e.g. definition of the problem, documentation, consideration of the constraints, experimentation, exploration, structuration, prototype, test, etc.) These items represent different cognitive phases involved the creative problem-solving approach. A highly selected stage indicated that the participants employ that particular resource frequently.

Our studies (Bourgeois-Bougrine, Sandoz, Allena, \& Dallez, 2015; Bourgeois-Bougrine et al., 2017) showed that the use of a "pencil and paper" workbook proved very useful in understanding engineering and scriptwriter students' creative process as well as evaluating the nature and effectiveness of the tool used. However, other types of support (computer tab, mobile phone, etc.) could be used to capture ideas at any time and place, record one's thoughts and progress as well as to participate in team projects in synchronous and asynchronous ways.

The evaluation of the medium-term impact of the training should be carried out through surveys at regular intervals with the students. In previous studies, we observed that hands on innovative projects allowed us to analyse the techniques and strategies that students used at each stage of the creative process and how successful or unsuccessful they were at using them (Bourgeois-Bougrine et al., 2017). However, it did not provide any insight neither about the change in student's attitudes and behaviour, nor regarding the transfer of knowledge gained from the whole experience. These surveys should focus on the new competencies implemented, the transfer of learned behaviours and the objective results obtained in professional situations: innovative products or services, patents, launch of start-ups, fund-raising to develop project, reduction of accidents, increase in customer satisfaction, increase in produc- 
tivity, profits and or savings, etc. Further, questionnaires and activities should be used prior to the workshop to assess the initial level of empathy among students, their teamwork and problem-solving skills, cognitive style and creative potential. The same evaluations will take place a few months after the workshop is completed to assess potential changes and progress.

\section{Conclusions}

Despite DT is promoted as human-centered design process to innovation, several challenges are hampering its successful implementation in organisations that requires a mindset change and the development of radial innovation skills. This paper proposed a new approach to engineering student's DT training that addressed two major critics of DT:

- the main limit of DT is related to the satisfaction of the actual user needs promoting mainly gradual improvement of existing services and products and preserving the status quo. Indeed, empathy towards users or customers' current needs might prevent radical or disruptive innovation, which involves the creation of new markets by anticipating non-expressed needs. Because of users' cultural context, previous experience and knowledge they might have difficulties anticipating their needs. In this paper, we explored the development of a methodology to enhance DT in education setting to favour radical innovation. The use of PE methods such as scenarios as well as digital tools and virtual environments should promote students' creativity and self-efficacy. PE methods help sweep the field of possibilities, identify key variables and issues of the future, reduce uncertainties about the future, make strategic decisions and actions about the future. Digital tools open new perspectives in the process of innovation, particularly in the field of DT with several notable advantages such as supporting idea generation, stimulating empathy and avoiding production loss. This can be achieved by holding ideation sessions in virtual worlds, using virtual 3D models and embodying creative avatars;

- the second critic of DT is related to the fact that is often based on anecdotes than data and that its value is difficult to prove. The assessment of what the participants have learned and the observed changes in their behaviour would provide answers about the potential benefits of this approach and the necessary improvements to introduce in terms of its organization and the quality of its programs.

The students' learning and integration of these methods should be evaluated in hands-on PPs. The approach presented in this paper aims to enable multi-disciplinary teams of students to get engaged in deeper learning of radical innovation-related skills as well as collaboration and communication. Should the behaviours and attitudes developed by students during this experiment be "transferable" to a professional situation, this would probably encourage the emergence of more innovative companies like NSs.

\section{References}

Altman, M., Huang, T. T. K., \& Breland, J. Y. (2018). Design thinking in health care. Preventing Chronic Disease 15. Retrieved from https://www.cdc.gov/pcd/issues/2018/18_0128.htm

American Psychological Association. (2018). Safety \& Design. Retrieved from http://www.apa.org/topics/safety-design/index.aspx 
Assink, M. (2006). Inhibitors of disruptive innovation capability: a conceptual model. European Journal of Innovation Management, 9(2), 215-233. https://doi.org/10.1108/14601060610663587

Baillie, C. (2002). Enhancing creativity in engineering students. Engineering Science and Education Journal, 11(5), 185-192. https://doi.org/10.1049/esej:20020503

Behm, M., Culvenor, J., \& Dixon, G. (2014). Development of safe design thinking among engineering students. Safety Science, 63, 1-7. https://doi.org/10.1016/j.ssci.2013.10.018

Bertrand, Ph., Guegan, J., Robieux, L., McCall, C. A., \& Zenasni, F. (2018). Learning empathy through virtual reality: multiple strategies for training empathy-related abilities using body ownership illusions in embodied virtual reality. Frontiers in Robotics and AI, 5, 1-18. https://doi.org/10.3389/frobt.2018.00026

Bourgeois-Bougrine, S., Buisine, S., Vandendriessche, C., Glaveanu, V., \& Lubart T. (2017). Engineering students' use of creativity and development tools in conceptual product design: what, when and how? Thinking Skills and Creativity, 24, 104-117. https://doi.org/10.1016/j.tsc.2017.02.016

Bourgeois-Bougrine, S., Richard, P., Lubart, T., Burkhardt, J. M., \& Frantz, B. (2018, 26-30 August). Do virtual environments unleash everyone's creative potential? In S. Bagnara, R. Tartaglia, S. Albolino, Th. Alexander, \& Y. Fujita (Eds.), Proceedings of the 20th Congress of the International Ergonomics Association (IEA 2018) (pp. 1328-1339). Series: Advances in Intelligent Systems and Computing. Vol. 824. Congress of the International Ergonomics Association. Florence.

https://doi.org/10.1007/978-3-319-96071-5_134

Bourgeois-Bougrine, S., Sandoz, B., Allena, R., \& Dallez, B. (2015, 17-18 September). Group creativity in biomedical engineering education. In R. P. Dameri \& L. Baltrametti (Eds.), ECIE 2015 10th European Conference on Innovation and Entrepreneurship (ECIE 2015) (90 p.). University of Genoa, Italy. Genoa, Italy.

Bradfield, R., Wright, G., Burt, G., Cairns, G., \& Heijden, Van Der K. (2005). The origins and evolution of scenario techniques in long range business planning. Futures, 37(8), 795-812. https://doi.org/10.1016/j.futures.2005.01.003

Brangier, E., Barcenilla, J., \& Robert, J-M. (2017). Prospective ergonomics and innovative ideas in the early stages of design projects. In A. Zunjic (Ed.), Ergonomic Design and Assessment of Products and Systems (pp. 47-68). New York: Nova Science Publishers.

Brangier, É., \& Robert, J-M. (2014). L'ergonomie prospective: fondements et enjeux. Le Travail Human, 1(77), 1-20. https://doi.org/10.3917/th.771.0001

Brown, T. (2009). Change by design: how design thinking transforms organizations and inspires innovation. New York: HarperCollins.

Brown, T., \& Katz, B. (2011). Change by design. The Journal of Product Innovation Management, 28(3), 381-383. https://doi.org/10.1111/j.1540-5885.2011.00806.x

Buerkli, D. (2013). Why the d.school has its limits. The Stanford Daily. Retrieved from https://www. stanforddaily.com/2013/03/07/why-the-d-school-has-its-limits/

Buisine, S., Guegan, J., Barré, J., Segonds, F., \& Aoussat, A. (2016). Using avatars to Tailor ideation process to innovation strategy. Cognition, Technology \& Work, 18(3), 583-594. https://doi.org/10.1007/s10111-016-0378-y

Buur, J., \& Matthews, B. (2008). Participatory innovation. International Journal of Innovation Management, 12(3), 255-273. https://doi.org/10.1142/S1363919608001996

Cahour, B. (2002). Décalages socio-cognitifs en réunions de conception participative. Le travail humain, 65(4), 315-337. https://doi.org/10.3917/th.654.0315

Cairns, G., Wright, G., Fairbrother, P., \& Phillips, R. (2017). "Branching scenarios" seeking articulated action for regional regeneration - a case study of limited success. Technological Forecasting and Social Change, 124, 189-202. https://doi.org/10.1016/j.techfore.2017.01.014 
Carlgren, L., Elmquist, M., \& Rauth, I. (2016). The challenges of using design thinking in industry experiences from five large firms. Creativity and Innovation Management, 25(3), 344-362. https://doi.org/10.1111/caim.12176

Diehl, M., \& Stroebe, W. (1987). Productivity loss in brainstorming groups: toward the solution of a riddle. Journal of Personality and Social Psychology, 53(3), 497-509. https://doi.org/10.1037/0022-3514.53.3.497

dschool.fr. (2018). d.school Paris. Retrieved from http://www.dschool.fr/

Dym, C. L., Agogino, A. M., Eris, O., Frey, D. D., \& Leifer, L. J. (2005). Engineering design thinking, teaching, and learning. The Research Journal for Engineering Education, 94(1), 103-120. https://doi.org/10.1002/j.2168-9830.2005.tb00832.x

economie.gouv.fr. (2015). Industrie du Futur: transformer le modèle industriel par le numérique. Retrieved from https://www.economie.gouv.fr/lancement-seconde-phase-nouvelle-france-industrielle

Friedman, R. S., \& Förster, J. (2010). Implicit affective cues and attentional tuning: an integrative review. Psychological Bulletin, 136(5), 875-893. https://doi.org/10.1037/a0020495

Gibbs, G. (1988). Learning by doing: a guide to teaching and learning methods. Oxford: Further Education Unit, Oxford Polytechnic.

Gordon, Th. J., \& Glenn, J. C. (2004, 13-14 May). Integration, comparisons, and frontier of futures research methods. EU-US Seminar: New Technology Foresight, Forecasting \& Assessment Methods (pp. 106-122). Seville.

Guegan, J., Buisine, S., Mantelet, F., Maranzana, N., \& Segonds, F. (2016). Avatar-mediated creativity: when embodying inventors makes engineers more creative. Computers in Human Behavior, 61, 165-175. https://doi.org/10.1016/j.chb.2016.03.024

Hussain, M., Tapinos, E., \& Knight, L. (2017). Scenario-driven roadmapping for technology foresight. Technological Forecasting and Social Change, 124, 160-177.

https://doi.org/10.1016/j.techfore.2017.05.005

iea.cc. (2018). International ergonomics association. Retrieved from http://www.iea.cc/whats/index.html

Iskander, N. (2018). Design thinking is fundamentally conservative and preserves the Status Quo. Harvard Business Review. Retrieved from https://hbr.org/2018/09/design-thinking-is-fundamentallyconservative-and-preserves-the-status-quo

Jaruzelski, B., Staack, V., \& Goehle, B. (2014). Global innovation 1000: proven paths to innovation success. Strategy+Business, 77. New York: PwC Strategy \& Inc.

Jouvenel, de H. (2002). La démarche prospective. Un bref guide méthodologique. Revue Futuribles 247. Retrieved from http://maelko.typepad.com/JouvenelProspective.pdf

Kirkpatrick Partners. (2009-2018). The Kirkpatrick model. Retrieved from https://www.kirkpatrickpartners.com/Our-Philosophy/The-Kirkpatrick-Model

Kolb, D. A. (1984). Experiential learning: experience as the source of learning and development. New Jersey: Prentice Hall, Inc.

Kristensson, P., \& Magnusson, P. R. (2010). Tuning users' innovativeness during ideation. Creativity and Innovation Management, 19(2), 147-159. https://doi.org/10.1111/j.1467-8691.2010.00552.x

Kristensson, P., Magnusson, P. R., \& Matthing, J. (2002). Users as a hidden resource for creativity: findings from an experimental study on user involvement. Creativity and Innovation Management, 11(1), 55-61. https://doi.org/10.1111/1467-8691.00236

Kujala, S. (2003). User involvement: a review of the benefits and challenges. Behaviour \& Information Technology, 22(1), 1-16. https://doi.org/10.1080/01449290301782

Kunc, M., \& O’Brien, F. A. (2017). Exploring the development of a methodology for scenario use: combining scenario and resource mapping approaches. Technological Forecasting and Social Change, 124, 150-159. https://doi.org/10.1016/j.techfore.2017.03.018 
Latorre, S., Markowski, K., \& Pointet, J.-M. (2016, 1-4 June). How do management and human behavior bring success to virtual collaboration? European Academy of Management (EURAM) 2016. Paris: European Academy of Management, Université Paris-Est Créteil (unpublished source).

Leifer, L. J., \& Steinert, M. (2011). Dancing with ambiguity: causality behavior, design thinking, and triple-loop-learning. Information, Knowledge, Systems Management, 10(1-4), 151-173.

Liedtka, J. (2015). Perspective: linking design thinking with innovation outcomes through cognitive bias reduction. The Journal of Product Innovation Management, 32(6), 925-938. https://doi.org/10.1111/jpim.12163

Lubart, T. I. (1999). Componential models. In M. A. Runco \& S. R. Pritzker (Eds.), Encyclopedia of Creativity (pp. 295-300). Vol. 1. San Diego, CA: Academic Press.

Lubart, T. (2003). Psychologie de la créativité. Series: Cursus. N. Bacri, C. Chiland, G. Moser, F. Winnykamen (Eds.). Paris: Armand Colin/VUEF.

Mathisen, G. E., \& Bronnick, K. S. (2009). Creative self-efficacy: an intervention study. International Journal of Educational Research, 48(1), 21-29. https://doi.org/10.1016/j.ijer.2009.02.009

McCullagh, K. (2010). Design thinking: everywhere and nowhere, reflections on the big re-think. Core77. Retrieved from https://www.core77.com/posts/16277/design-thinkingeverywhere-andnowhere-reflections-on-the-big-re-think-16277

McGregor, J. (2007). Clayton Christensen's innovation brain. Bloomberg. Retrieved from https://www. bloomberg.com/news/articles/2007-06-15/clayton-christensens-innovation-brainbusinessweekbusiness-news-stock-market-and-financial-advice

McKiernan, P. (2017). Prospective thinking; scenario planning meets neuroscience. Technological Forecasting and Social Change, 124, 66-76. https://doi.org/10.1016/j.techfore.2016.10.069

McWilliam, E. (2009). Teaching for creativity: from Sage to Guide to Meddler. Asia Pacific Journal of Education, 29(3), 281-293. https://doi.org/10.1080/02188790903092787

Norman, D. (2013). The design of everyday things. New York: Basic Books.

Norman, D. A., \& Verganti, R. (2012). Incremental and radical innovation: design research versus technology and meaning change. Design Issues, 30(1), 78-96. https://doi.org/10.1162/DESI_a_00250

Nussbaum, B. (2011). Design thinking is a failed experiment. So what's next? Fast company. Retrieved from https://www.fastcompany.com/1663558/design-thinking-is-a-failed-experiment-so-whats-next

O'Brien, F. A. (2004). Scenario planning - lessons for practice from teaching and learning. European Journal of Operational Research, 152(3), 709-722. https://doi.org/10.1016/S0377-2217(03)00068-7

P21: Partnership for 21st Century Learning. (2018). Framework for 21st century learning. Retrieved from http://www.p21.org/our-work/p21-framework

Patnaik, D., \& Mortensen, P. (2009). Wired to care: how companies prosper when they create widespread empathy. San Mateo, CA: Jump Associates LLC.

Pescovitz, D., Rucker, R., Ellis, W., Naam R., Ashby, M., Sterling, B., \& Doctorow, C. (2013). An aura of familiarity: visions from the coming age of networked matter. Palo Alto, CA: Institute for the Future.

Pink, D. H. (2006). A whole new mind: why right-brainers will rule the future. New York: Riverhead Books.

Plattner, H. (2010). An introduction to design thinking: process guide. Stanford: Institute of Design at Stanford.

Robert, J.-M., \& Brangier, E. (2009). What is prospective ergonomics? A reflection and a position on the future of ergonomics. In B.-T. Karsh (Ed.), Ergonomics and Health Aspects of Work with Computers (pp. 162-169). HCI International 2009, LNCS 5624. Berlin, Heidelberg: Springer-Verlag.

Scott, G., Leritz, L. E., \& Mumford, M. D. (2004). The effectiveness of creativity training: a quantitative review. Creativity Research Journal, 16(4), 361-388. https://doi.org/10.1080/10400410409534549 
Seelig, T. (2012). inGenius: a crash course on creativity. New York: HarperCollins Publishers.

Seidel, V. P., \& Fixson, S. K. (2013). Adopting design thinking in novice multidisciplinary teams: the application and limits of design methods and reflexive practices. The Journal of Product Innovation Management, 30(S1), 19-33. https://doi.org/10.1111/jpim.12061

Shin, D. (2018). Empathy and embodied experience in virtual environment: to what extent can virtual reality stimulate empathy and embodied experience? Computers in Human Behavior, 78, 64-73. https://doi.org/10.1016/j.chb.2017.09.012

Stanton, N., Hedge, A., Brookhuis, K., Salas, E., \& Hendrick, H. (2005). Handbook of human factors and ergonomics methods. Boca Raton, London, New York, Washington, D.C.: CRC Press LLC.

Steidle, A., \& Werth, L. (2013). Freedom from constraints: darkness and dim illumination promote creativity. Journal of Environmental Psychology, 35, 67-80. https://doi.org/10.1016/j.jenvp.2013.05.003

Thornhill-Miller, B., \& Dupont, J.-M. (2016). Virtual reality and the enhancement of creativity and innovation: under recognized potential among converging technologies? Journal of Cognitive Education and Psychology, 15(1), 102-121. https://doi.org/10.1891/1945-8959.15.1.102

Verganti, R. (2010). User-centered innovation is not sustainable. Harvard Business Review. Retrieved from https://hbr.org/2010/03/user-centered-innovation-is-no

Ware, C. (2008). Visual thinking for design: active vision, attention, visual queries, gist, visual skills, color, narrative, design. Series: The Morgan Kaufmann Series in Interactive Technologies. S. Card, J. Grudin, \& J. Nielsen (Eds.). Amsterdam: Morgan Kaufmann Publishers, Elsevier Inc.

Wikipedia: The Free Encyclopedia. (2018). Hill climbing. Retrieved from https://en.wikipedia.org/wiki/ Hill_climbing

Wright, G., Cairns, G., \& Goodwin, P. (2009). Teaching scenario planning: lessons from practice in academe and business. European Journal of Operational Research, 194(1), 323-335.

https://doi.org/10.1016/j.ejor.2007.12.003

Wrigley, C., Mosely, G., \& Tomitsch, M. (2018). Design thinking education: a comparison of massive open online courses, She Ji: The Journal of Design, Economics, and Innovation, 4(3), 275-292. https://doi.org/10.1016/j.sheji.2018.06.002

Yang, Ch. M. (2018). Applying design thinking as a method for teaching packaging design. Journal of Education and Learning, 7(5), 52-61. https://doi.org/10.5539/jel.v7n5p52

Yee, N., Bailenson, J. N., \& Ducheneaut, N. (2009). The proteus effect: implications of transformed digital self-representation on online and offline behavior. Communication Research, 36(2), 285-312. https://doi.org/10.1177/0093650208330254

\section{NEIŠREIKŠTŲ KŪRYBINĖS VAIZDUOTĖS POREIKIŲ SKATINIMAS: MIŠRAUS POŽIŪRIO İ DIZAINERIŠKOS MĄSTYSENOS STIPRINIMĄ TYRIMAS}

\section{Samira BOURGEOIS-BOUGRINE, Souad LATORRE, Florence MOUREY}

\section{Santrauka}

Kūrybiškumas - iš esmès svarbus radikalioms inovacijoms, generuojant naujas ir griaunančias idejjas. Vadovai, praktikuojantys specialistai ir desstytojai vis labiau integruoja dizaineriškos mąstysenos metodą, siekdami sužadinti kūrybiškumą ir inovacijas. Dizaineriška mąstysena reiškia empatiją kaip inovacija grindžiamą požiūrị, kuriuo siekiama suprasti slaptus vartotojų, stebètų realiomis aplinkybėmis, poreikius. Vis dèlto buvo teigiama, kad radikalios inovacijos nekyla iš požiūrio, sutelkto 
i̇ vartotojus, tokio kaip dizaineriška mąstysena, ir kad tokia mąstysena dažnai grindžiama pavieniais atvejais, o ne duomenimis bei tuo, kad jos vertę sunku ịrodyti. Šio straipsnio tikslai - pateikti požiūrị, kuris padidintų dizaineriškos mąstysenos vertę lavinimo aplinkoje, siekiant palaikyti radikaliomis inovacijomis grindžiamą mąstymo būdą. Atsižvelgiant ị ateities ergonomikos nešamą naudą, skaitmeninị modelị ir virtualią aplinką, skirtą idejjizavimui ir empatizavimui paskatinti, siūlomas požiūris yra it pradinis taškas, ịsivaizduojant ateities poreikius, pasitelkiant ateities scenarijų atvejus, o ne slaptus ir nepatenkintus vartotojų poreikius, siekiant žmogaus darbo produktų ir paslaugų, kurios pakeistų socialines praktikas, plètros. Straipsnyje svarstoma, kodèl ir kaip šis mišrus požiūris paskatintų studentų radikalių inovacijų igūdžius, ne tik patenkinant tikruosius vartotojų poreikius, bet ịsivaizduojant ir numatant naujus, taip pat pateikiamas metodas, skirtas dizaineriškos mąstysenos tobulinimo veiksmingumui įvertinti.

Reikšminiai žodžiai: kūrybiškumas, dizaineriška mąstysena, skaitmeninès technologijos, lavinimas, ergonomika, inovacijos, poreikių ieškantys asmenys, ateities ergonomika. 